\title{
Correction: CircPVT1 promotes gallbladder cancer growth by sponging miR-339-3p and regulates MCL-1 expression
}

Shouhua Wang, Ting ting Su, Huanjun Tong, Weibin Shi, Fei Ma and Zhiwei Quan (D)

(c) The Author(s) 2021

Cell Death Discovery (2021)7:396; https://doi.org/10.1038/s41420-021-00669-9

Correction to: Cell Death Discovery https://doi.org/10.1038/s41420-

021-00577-y, published online 26 July 2021

In this article, a minor concern regarding Figure 6 have been noticed by Shouhua Wang et al., which is no impact on the final finding and conclusion, they made an error for label for miR-339-3p in the Figure $6 \mathrm{C}-\mathrm{H}$, the label for miR-338-3p or miR-33p-3p should be miR-339-3p, the figure legends and figure data is right. A modified composite figure has now been created. The amended figure is shown below. The authors express regrets for their error. 

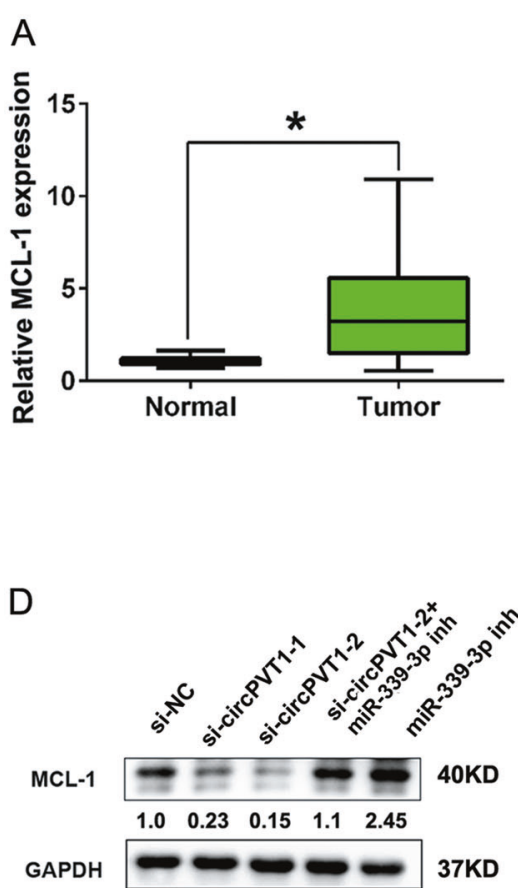

NOZ

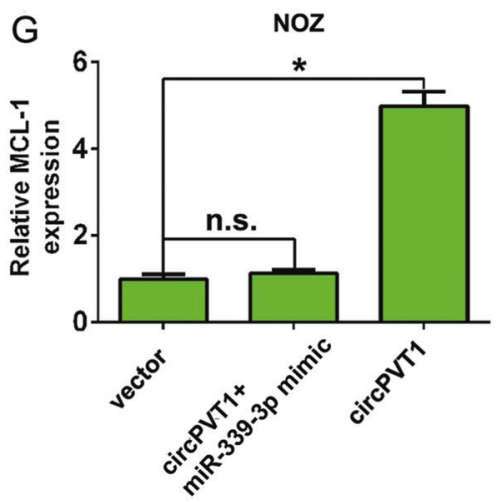

$\mathrm{H}$

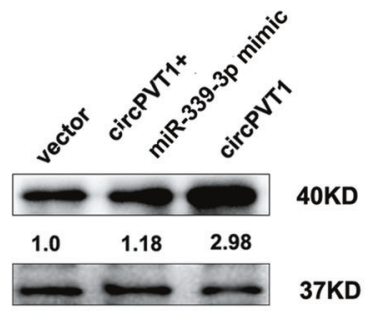

NOZ
B

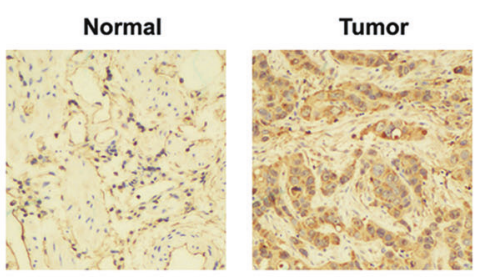

MCL-1

E

C

NOZ

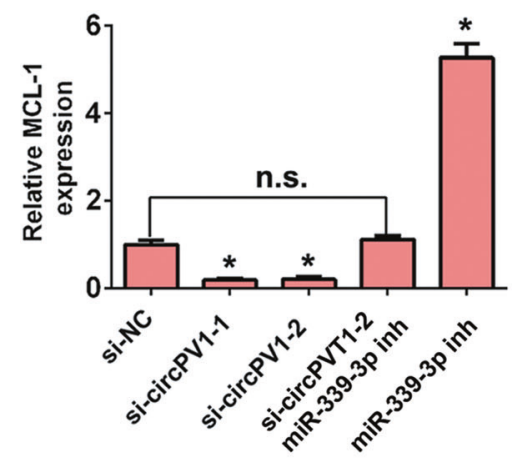

F

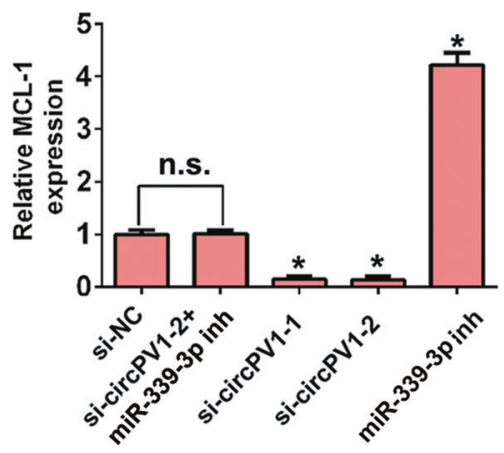

MCL-1

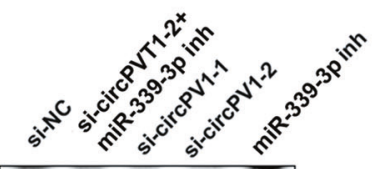

GAPDH

$\begin{array}{lllll}1.0 & 0.98 & 0.13 & 0.1 & 1.96\end{array}$

40KD

$37 K D$
(2) Open Access This article is licensed under a Creative Commons Attribution 4.0 International License, which permits use, sharing, adaptation, distribution and reproduction in any medium or format, as long as you give appropriate credit to the original author(s) and the source, provide a link to the Creative Commons license, and indicate if changes were made. The images or other third party material in this article are included in the article's Creative Commons license, unless indicated otherwise in a credit line to the material. If material is not included in the article's Creative Commons license and your intended use is not permitted by statutory regulation or exceeds the permitted use, you will need to obtain permission directly from the copyright holder. To view a copy of this license, visit http://creativecommons. org/licenses/by/4.0/.

(c) The Author(s) 2021 